\title{
Cell-Wall Hydrolases as Antimicrobials against Staphylococcus Species: Focus on Sle1
}

\author{
Aurore Vermassen ${ }^{1}$, Régine Talon ${ }^{1}$, Carine Andant ${ }^{1}$, Christian Provot ${ }^{2}$, Mickaël Desvaux ${ }^{1}$ (D) \\ and Sabine Leroy ${ }^{1, *}$ \\ 1 Université Clermont-Auvergne, INRA, MEDIS, F-63000 Clermont-Ferrand, France; \\ aurore.vermassen@educagri.fr (A.V.); regine.talon@inra.fr (R.T.); carine.andant@inra.fr (C.A.); \\ mickael.desvaux@inra.fr (M.D.) \\ 2 BioFilm Control, Biopôle Clermont Limagne, F-63360 Saint-Beauzire, France; \\ christian.provot@biofilmcontrol.com \\ * Correspondence: sabine.leroy@inra.fr
}

Received: 25 October 2019; Accepted: 7 November 2019; Published: 12 November 2019

\begin{abstract}
Some staphylococcal species are opportunistic pathogens of humans and/or animals with Staphylococcus epidermidis as one of the most important. It causes a broad spectrum of diseases in humans and animals. This species is able to form biofilms and has developed antibiotic resistance, which has motivated research on new antibacterial agents. Cell-wall hydrolases (CWHs) can constitute a potential alternative. Following a hijacking strategy, we inventoried the CWHs of S. epidermidis. The lytic potential of representative CWHs that could be turned against staphylococci was explored by turbidity assays which revealed that cell wall glycosidases were not efficient, while cell wall amidases and cell wall peptidases were able to lyse S. epidermidis. Sle1, which is encoded by chromosomal gene and composed of three anchoring LysM domains and a C-terminal CHAP (cysteine, histidine-dependent amidohydrolase/peptidase) domain, was one of the most active CWHs. The phylogeny of Sle1 revealed seven clusters mostly identified among staphylococci. Sle1 was able to lyse several staphylococcal species, including Staphylococcus aureus, both in planktonic and sessile forms, but not Micrococcus.
\end{abstract}

Keywords: cell wall hydrolases; staphylococci; lytic activity; phylogeny

\section{Introduction}

Staphylococci are mainly associated with the skin, skin glands and mucous membranes of animals and humans [1,2]. The genus includes more than 51 species (www.bacterio.net) divided into two groups according the coagulase test, with nine species of coagulase positive staphylococci (CPS) and a vast group of coagulase negative species (CNS). Some species are opportunistic pathogens of humans and/or animals with Staphylococcus aureus (CPS) and Staphylococcus epidermidis (CNS) as the most important ones. They cause a broad spectrum of diseases ranging from skin diseases, wound sepsis, mastitis, endocarditis, osteomyelitis, and lung infections in humans and animals [2,3]. In a survey of the prevalence of healthcare-associated infections (HAI) and antimicrobial use in Europe, $7.1 \%$ of patients had at least one HAI and 34.6\% received one antimicrobial agent (e.g., antibiotic) [4]. Staphylococci were commonly isolated from HAI and represented $35.2 \%$ of all types of infections, $54.3 \%$ at surgical sites and $41.7 \%$ in blood stream infections. S. aureus was found in $12.1 \%$ of all types of infections and in $21.5 \%$ of surgical site infections, with $34.2 \%$ of strains resistant to methicillin. CNS accounted for $8.3 \%$ of all types of infections, $13.4 \%$ of surgical site infections, and $16.7 \%$ of blood stream infections [4]. Among CNS species, S. epidermidis is predominant in clinical isolates and can act as a reservoir of antibiotic resistance genes for $S$. aureus [2,5]. The population structure of $S$. 
epidermidis appears epidemic with the emergence of well-adapted clones evolving rapidly through genetic recombination by frequent transfer of genetic mobile elements such as staphylococcal cassette chromosome mec (SCCmec) elements [2]. Furthermore, S. epidermidis as well as S. aureus are able to form biofilms on biotic and abiotic surfaces [3,6-9].

The antibiotic resistance of these two species has motivated research on new antibacterial agents. Cell-wall hydrolases (CWHs) constitute a potential alternative. These ubiquitous bacterial enzymes hydrolyze peptidoglycan and play a key role in cell growth, separation and turnover but also in cell lysis. They are classified into three classes according their conserved catalytic domains, amidases, glycosidases and peptidases [10]. Only a few CWHs are described in staphylococci, including lysostaphin, Atl, Sle1 and LytN [10,11]. Lysostaphin isolated from Staphylococcus simulans is one of the most studied cell-wall peptidases (CWPs). It cuts the peptide bond between the third and fourth glycine residues of the pentaglycine cross-link in the peptidoglycan of staphylococci [11,12]. The major hydrolase Atl (AtlA in S. aureus, AtlE in S. epidermidis and AtlL in Staphylococcus lugdunensis) is a bifunctional enzyme composed of one cell-wall amidase (CWA) and one cell-wall glucosamidase (CWG) domain separated by anchoring domains $[11,13,14]$. They are synthesized as propeptides and cleaved by an extracellular protease to generate two extracellular enzymes, namely a $51 \mathrm{kDa}$ endo- $\beta-N$-acetylglucosaminidase (GHF-73) and a $62 \mathrm{kDa} N$-acetylmuramoyl-L-alanine amidase (NALAA-2), which are independently involved in the partitioning of daughter cells after cell division [15]. Atl was also shown to be involved in virulence by its adhesive properties and to elicit protective immunity against S. aureus and S. epidermidis $[15,16]$ and in the internalization of S. lugdunensis by eukaryotic cells [17]. In S. aureus, Sle1 composed of three anchoring LysM domains and a C-terminal CHAP (cysteine, histidine-dependent amidohydrolase/peptidase) domain is also required for cell separation [18,19]. The CHAP domain is potentially involved in two different activities: as a peptidase, it cleaves between D-alanine and the first glycine of the pentaglycine cross-bridge and it can also act as an amidase by cleaving the chemical bond between MurNAc and L-alanine at the N-terminal of the stem peptide [20,21]. In S. epidermidis and S. aureus, Sle1, was essentially characterized for its adhesive properties to extracellular matrix proteins and further named Aae (autolysin/adhesin in S. epidermidis) and Aaa (autolysin/adhesin in S. epidermidis), respectively [6,22]. The murein hydrolase LytN harbors one LysM (instead of three as in SleI) and one CHAP domain, and promotes peptidoglycan separation and completion of the S. aureus cell cycle [23]. LytH, a L-Ala-D-Glu endopeptidase, identified in S. aureus, is involved in methicillin resistance [24].

Although these CWHs may be potentially promising staphylococcal lethal weapons, their lytic activity remains to be explored. This observation prompted us to inventory the CWHs of S. epidermis and explore their lytic potential. Here, we identify 16 hydrolases in the S. epidermidis RP62A strain, provide evidence of the activity of 11 representatives of the three catalytic domains and demonstrate the high potential of the Sle1 hydrolase in lysis of staphylococci.

\section{Materials and Methods}

\subsection{Bacterial Strains and Culture Conditions}

Different strains of Staphylococcus belonging to nine species were used: 11 Staphylococcus epidermidis (RP62A, ATCC 12228, S06-011, S06-013, S06-022, S04-028, S04-036, S04-038, S04-056, S04-057, S04-058) isolated from medical samples [25,26], Staphylococcus xylosus C2a [27], Staphylococcus aureus (MW2, UAMS-1, Coch, SA113, S30) isolated from medical samples [25,28,29], Staphylococcus simulans DSM20273, Staphylococcus saprophyticus CIP 76.125 $5^{\mathrm{T}}$, Staphylococcus hominis CIP $81.57^{\mathrm{T}}$, Staphylococcus haemolyticus CIP 81.56 ${ }^{\mathrm{T}}$, Staphylococcus hyicus DSM 20459 ${ }^{\mathrm{T}}$, and Staphylococcus sciuri CIP 81.62 . One strain of Micrococcus aurantiacus ATCC 11731 was also used. They were grown at $37^{\circ} \mathrm{C}$ in Tryptic Soy Broth (TSB, Sigma-Aldrich, St. Louis, MO, USA) with orbital shaking (150 rpm) or on Tryptic Soy Agar plates (TSA, Sigma-Aldrich). 
Escherichia coli strain TOP10 (Invitrogen, Carlsbad, CA, USA) was used as the cloning host for propagation of expression vector and used for protein expression. It was grown at $37^{\circ} \mathrm{C}$ in lysogeny broth (LB) with orbital shaking $(200 \mathrm{rpm})$ or on agar medium supplemented with ampicillin $(100 \mu \mathrm{g} / \mathrm{mL})$ when appropriate. Protein expression was induced by adding L-arabinose $(0.2 \% w / v)$ (Sigma-Aldrich).

\subsection{Proteogenomic Identification of $\mathrm{CWHs}$}

Considering the three classes of CWHs, the different conserved catalytic domains corresponding to CWAs, CWGs, and CWPs, as recently reviewed [10], were searched in S. epidermidis RP62A following a proteogenomic approach. These conserved domains were identified in proteins encoded in the genome of S. epidermidis RP62A following searches against InterPro (IPR) [30], which is composed of different member databases, such as Pfam [31], SMART [32], or the Conserved Domain database (CD) [33] where the identification of a conserved motif is based on a probabilistic match against HMM (hidden Markov model) or even PSSM (position-specific scoring matrix) profiles, which are more effective, relevant and robust than a percentage of identity or similarity against regular expressions [34].

\subsection{Cloning and Expression of Hydrolases}

DNA from S. epidermidis RP62A was used as a template to amplify the CDS encoding 11 different hydrolases. The primers used for PCR are listed in Table S1 and were synthesized by Eurofins Genomics. Amplifications were performed using Phusion High-Fidelity DNA polymerase (New England Biolabs) and the amplicons were then gel-purified using the QIAquick gel extraction kit (Qiagen, Hilden, Germany). PCR fragments were digested by KpnI/EcoRI or Pst /KpnI and cloned in-frame downstream of the hexa-His box sequence in the $\mathrm{pBAD} / \mathrm{His} \mathrm{B}$ vector (Invitrogen) precut with the same restriction enzymes using T4 DNA Ligase (Roche, Basel, Switzerland). Plasmid constructions were transformed into E. coli TOP10 competent cells prior to selection on LB agar supplemented with ampicillin. E. coli TOP10 competent cells were also transformed with the empty $\mathrm{pBAD} / \mathrm{His} \mathrm{B}$ vector plasmid as a control. DNA sequencing was carried out to confirm the correct nucleotide sequence of the constructs using forward priming site and reverse priming site primers (Invitrogen, pBAD-F and pBAD-R, Table S1) and the Mix2Seq Kit (Eurofins Genomics).

Overnight precultures of E. coli recombinant strains were diluted 1:100 and grown in $100 \mathrm{~mL}$ of $\mathrm{LB}$ supplemented with ampicillin until $\mathrm{OD}_{600 \mathrm{~nm}}=0.6$. At this point, protein expression from $\mathrm{pBAD}$ was induced by adding L-arabinose and the cultures were incubated for a further $4 \mathrm{~h}$ at $37^{\circ} \mathrm{C}$ and $20 \mathrm{~h}$ at $20^{\circ} \mathrm{C}$. Cells were harvested by centrifugation, washed in PBS $(0.01 \mathrm{M}, \mathrm{pH} 8)$ and stored at $-20{ }^{\circ} \mathrm{C}$. They were suspended in $50 \mathrm{mM} \mathrm{NaH}_{2} \mathrm{PO}_{4}, 300 \mathrm{mM} \mathrm{NaCl}$ buffer $(\mathrm{pH}$ 8) and disrupted with glass microbeads (400 mg per $\mathrm{mL}$ ) using FastPrep $\left(20 \mathrm{~s}\right.$ twice at $\left.6 \mathrm{~m} \cdot \mathrm{s}^{-1}\right)$. Crude protein lysates were collected in the supernatant after elimination of unbroken cells and cellular debris by centrifugation $(\mathrm{g}$, $45 \mathrm{~min}, 4^{\circ} \mathrm{C}$ ). The crude protein extracts and the control extract (i.e., the crude protein lysate from cells containing $\mathrm{pBAD}$ without insert) were then filtered through a $0.45 \mu \mathrm{m}$ membrane filter and were frozen at $-20^{\circ} \mathrm{C}$.

\subsection{Western Blot Analysis}

Protein concentrations were determined using the Bradford method [35]. The crude protein extracts were separated by SDS-PAGE after dilution in Laemmli buffer and heating to $95^{\circ} \mathrm{C}$ for $5 \mathrm{~min}$. Equal amounts of each extract were loaded per lane using Mini-PROTEAN TGX Precast Gels, $4 \%-15 \%$ (Bio-Rad). Precision Plus Protein Dual Color Standards (Bio-Rad) were used to enable molecular mass estimation as well as transfer control. Proteins resolved by SDS-PAGE were transferred to a PVDF membrane (iBlot ${ }^{\circledR} 2$ Transfer Stack) using iBlot ${ }^{\circledR} 2$ Dry Blotting system (Invitrogen). Membranes were blocked for $1 \mathrm{~h}$ using 10\% skim milk in PBS and were probed with specific anti-His-Tag antibodies (dilution 1/1000 in PBS with 0.1\% Tween and 2\% skim milk, for $1.5 \mathrm{~h}$ at room temperature, Monoclonal Anti-polyhistidine-peroxidase antibody produced in mouse, Sigma-Aldrich). Finally, the SuperSignal 
West Dura kit (ThermoFisher, Waltham, MA, USA), a luminol-based enhanced chemiluminescent substrate, was used to detect peroxidase activity.

\subsection{Cells Lysis Assay}

Lysis assays of all crude protein extracts were performed. The S. epidermidis strain RP62a was grown in TSB with $1 \mathrm{M} \mathrm{NaCl}$ until $\mathrm{OD}_{600 \mathrm{~nm}}=0.8$. Cultures were centrifuged, washed and resuspended in Tris buffer ( $50 \mathrm{mM}$ Tris-HCl, pH 7.0, Sigma-Aldrich) to $\mathrm{OD}_{600 \mathrm{~nm}}$ of 0.6. Subsequently, $100 \mu \mathrm{L}$ of crude protein extract $(1.6 \pm 0.2 \mathrm{mg} / \mathrm{mL})$ was added to $1 \mathrm{~mL}$ of cell suspension and placed in a cuvette covered with Parafilm. Cuvettes were incubated at $37^{\circ} \mathrm{C}$ and lysis was followed at $\mathrm{OD}_{600 \mathrm{~nm}}$ at $0,0.5$, $1,2,3$ and $4 \mathrm{~h}$. The control extract was tested in the same conditions in each experiment. Lysis was expressed after subtraction of the control extract as a percentage of lysis from T0. The experiments were performed at least in triplicate.

The lytic activity of Sle1 crude extract was also tested against all Staphylococcus strains and the strain of $M$. aurantiacus as described above. It was studied at different temperatures of incubation (4, $\left.10,20,25,30,37^{\circ} \mathrm{C}\right)$ and different $\mathrm{pHs}(5.5,7.0,9.0)$ in Tris buffer adjusted with $\mathrm{HCl}$ or $\mathrm{NaOH}$ or in physiological saline solution $(0.85 \%)$. It was also tested on biofilms of two S. epidermidis and S. aureus strains. Overnight precultures were adjusted at $\mathrm{OD}_{600 \mathrm{~nm}}=0.01 \mathrm{in}$ TSB and $200 \mu \mathrm{L}$ was loaded into the wells of a 96-well polystyrene microtiter plate prior to static incubation at $37^{\circ} \mathrm{C}$. After $24 \mathrm{~h}$ of incubation, the supernatant was removed and the adhered cells were washed. Crude protein extract of Sle1 ( $20 \mu \mathrm{L}$ in $200 \mu \mathrm{L}$ of Tris buffer) or control extract was then added. The microtiter plates were incubated for $4 \mathrm{~h}$ at $37^{\circ} \mathrm{C}$. The supernatant was removed and adhered cells were washed, fixed with alcohol, stained with $0.1 \%$ crystal violet, and treated with $33 \%$ acid acetic. The absorbance was read at $600 \mathrm{~nm}$. Six biological replicates were carried out for each condition.

\subsection{Phylogenetic Analysis of Sle1 Protein Sequence}

A homology search was performed using the amino acid sequence of Sle1 from S. epidermidis RP62A as query following BLAST against UniProtKB $[36,37]$. The recovered protein sequences ( $E$-value threshold $10^{-10}$ ) were aligned using T-Coffee [38]. The relatedness among protein sequences was studied using a Neighbor-Net phylogenetic network approach with SplitsTree v4.14.8 using the Hamming uncorrected-P distance [39]. The most robust branches were identified by bootstrap using a $90 \%$ threshold over 1000 pseudo-replicates.

\section{Results}

\subsection{Selection of Cell-Wall Hydrolases in S. Epidermidis RP62A}

The search in the UniProt database resulted in a list of 16 CWHs identified in S. epidermidis RP62A (Figure 1). They were classified according to their catalytic domains [10]. We identified CWHs with one catalytic domain, namely i) one CWA corresponding to N-acetylmuramoyl-L-alanine amidases (NALAA-3), ii) four CWGs including two $N$-acetylglucosaminidases (GHF-73), and one lysozyme (GHF-25) and a transglycosylase (TG), and iii) eight CWPs including seven Cysteine Histidine-dependent Amidohydrolases/Peptidases (CHAP) and one PM23. We also identified three bifunctional CWHs, one CWA/CWG (NALAA-2/GHF-73), one CWP/CWA (CHAP/NALAA-3) and one CWG/CWP (GHF-73/CHAP). Beside the catalytic domains, five of these CWHs have cell-wall binding domains such as $\mathrm{SH} 3$ (SH3-8, SH3-3) and LysM (Figure 1).

Eleven representative $\mathrm{CWH}$ s were selected to test their lytic activities against $\mathrm{S}$. epidermidis RP62A (Figure 1). The corresponding genes without signal peptide sequence were cloned into expression vector. To ensure all the CWHs were expressed in E. coli, Western blot analyses of crude protein extracts were performed (Figure S1). All the CWHs were produced but the protein expression levels varied. 


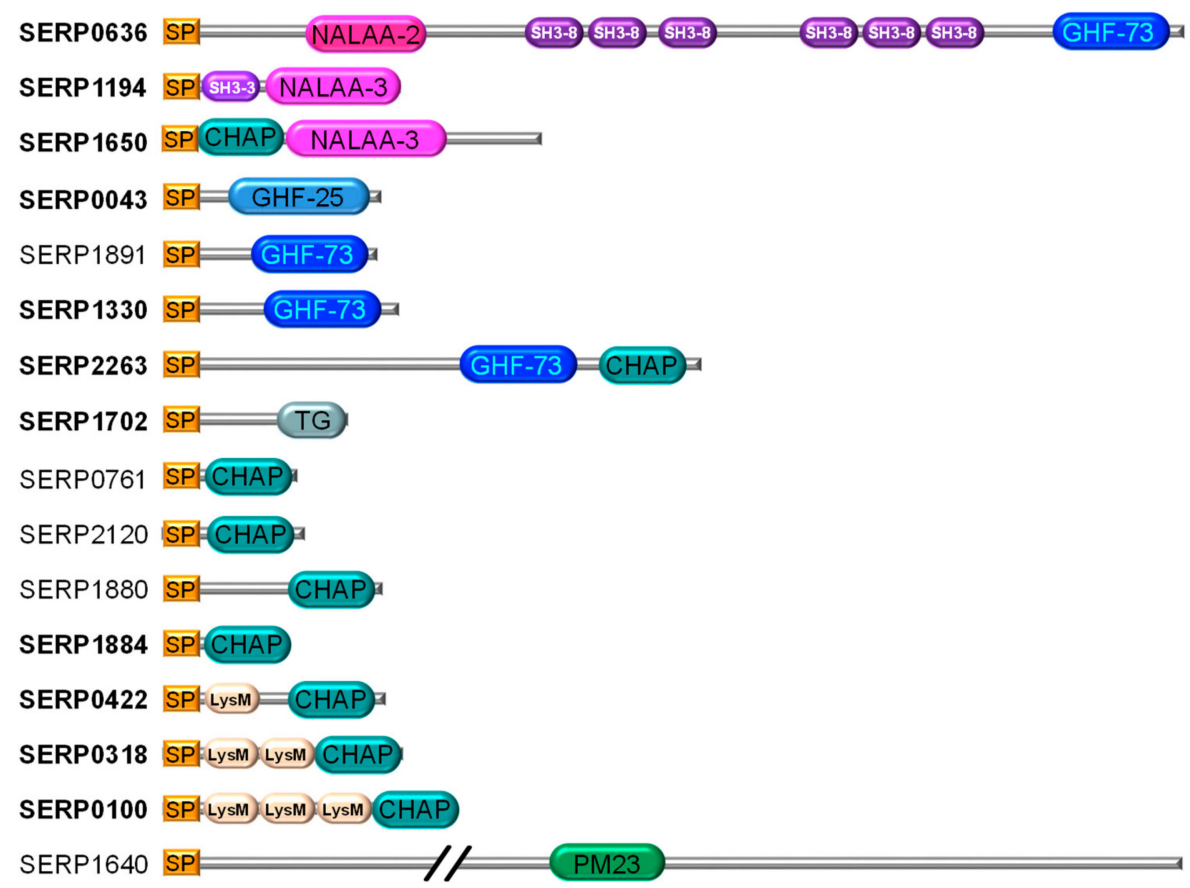

Figure 1. Schematic representation of cell-wall hydrolases (CWHs) identified in Staphylococcus epidermidis RP62A. SP: signal peptide, SH3, LysM: anchoring domain, NALAA: amidase domain, GHF: glycosidase domain, CHAP, PM23: peptidase domain, TG: transglycosylase. S. epidermidis RP62A locus names in bold were selected to study their lytic activity. SERP0636, SERP1194, SER0100 correspond to AtlE, LytH and Sle1, respectively.

\subsection{Lytic Activity of the 11 Hydrolases on Planktonic Cells of S. Epidermidis RP62A}

The lytic activity of the 11 hydrolases was studied as crude protein extracts $(1.6 \pm 0.2 \mathrm{mg} / \mathrm{mL})$ against $\mathrm{S}$. epidermidis RP62A. The results are summarized according to their catalytic domains in Figure 2. Overall, the CWGs were not able to lyse S. epidermidis RP62A, while all the other CWHs could (Figure 2). Indeed, the two CWGs (SERP0043, SERP1330) and the transglycosylase (SERP1702) with three different catalytic domains (GHF-25, GHF-73, transglycosylase) and no anchoring domain (Figure 1) did not have any lysis activity (Figure 2A). The CWA SER1194, with a NALAA type 3 catalytic domain and SH3-3 anchoring in the N-terminal region (Figure 1), caused $20 \%$ of lysis (Figure 2 B). The four CWPs had lytic activities with three showing activity ranging from $13 \%$ to $25 \%$ while SRP0100 (Sle1) had a strong lytic activity with 59\% of lysis after $3 \mathrm{~h}$ (Figure 2C) despite an apparent low production (Figure S1). The three CWPs SERP0422, SERP0318 and Sle1 have a CHAP catalytic domain but differ in their number of LysM anchoring domains (Figure 1). Sle1 had the highest number of LysM and was the most effective. The three bifunctional CWHs, although produced at the same level (Figure S1), lysed S. epidermidis with different efficiencies (Figure 2D). SERP0636 (AtlE) composed of two catalytic domains, NALAA-2/GHF-73, and six SH3-8 anchor domains (Figure 1), was the most active with $45 \%$ lysis (Figure 2D). The bi-functional enzymes, SERP1650 with CHAP/NALAA-3 and SERP2263 with GHF-73/CHAP catalytic domains, caused $29 \%$ and $15 \%$ of lysis, respectively (Figure 2D). 
A

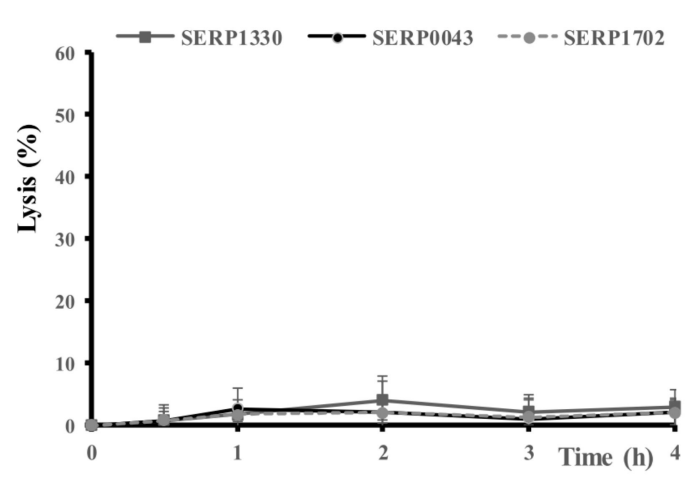

$\mathrm{C}$

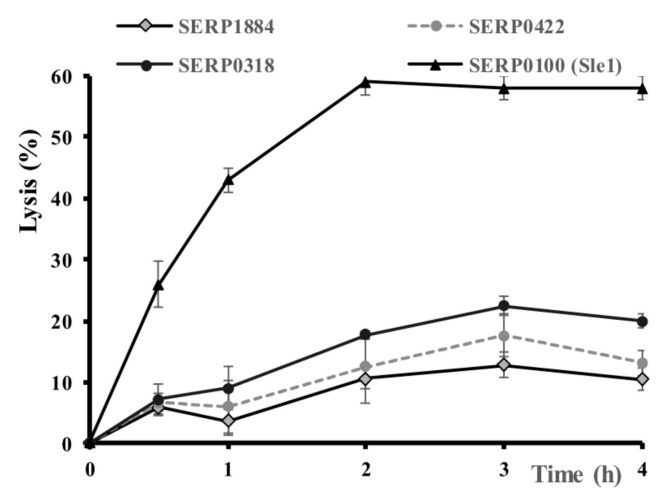

B

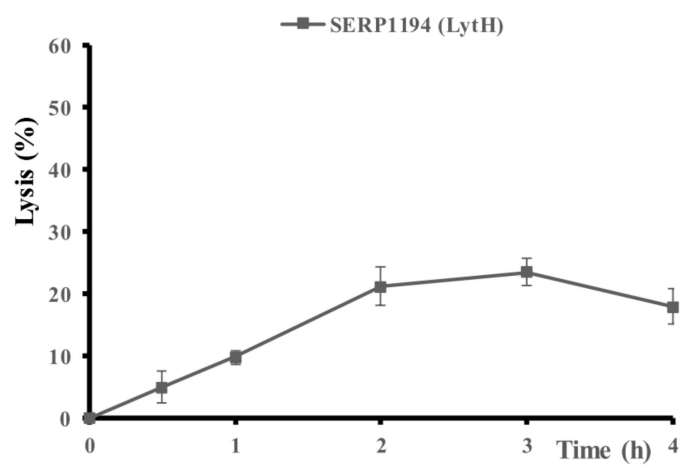

$\mathrm{D}$

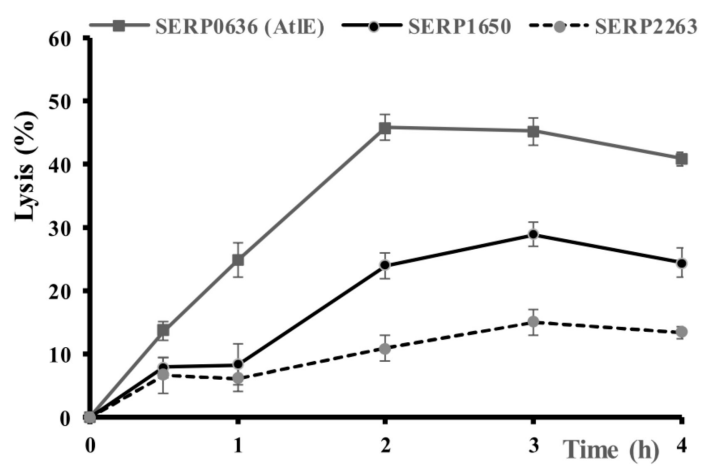

Figure 2. Lytic activity at $\mathrm{pH} 7.0$ and $37^{\circ} \mathrm{C}$ of the cell-wall glycosidase (A), amidase (B), peptidase (C) and bifunctional hydrolase (D) extracts on Staphylococcus epidermidis RP62A. Cell lysis was monitored at $\mathrm{OD}_{600 \mathrm{~nm}}$ over time, the control extract was subtracted and lysis was expressed as a percentage from T0.

From these results, Sle1 appears as a promising CWH at least against S. epidermidis RP62A and was selected further characterization.

\subsection{Diversity of Sle1}

Sle1 is composed of three LysM anchoring domains and a catalytic CHAP domain (Figure 1). In order to position Sle1 from S. epidermidis RP62A in the Sle1 family, a phylogenetic analysis was carried out (Table S2). Following sequence alignment of Sle1 homologs, the phylogenetic tree revealed seven clusters and four deeply rooted branches (Figure 3). Cluster 1 includes Sle1 from S. epidermidis RP62A and constitues the largest group comprising staphylococcal Sle1 homologs such as S. epidermidis-S. capitis, S. haemolyticus-S. hominis, S. warneri-S. pasteuri clusters. Note that some Sle1 homologs found in some Gram-negative bacteria were also identified within this cluster (Table S2). With the exception of clusters 4 and 5, all other clusters also include Sle1 homologs essentially found within the genus Staphylococcus. It is of note that clusters 3 and 6 essentially comprised Sle1 homogs found in S. hyicus-intermedius and in S. saprophyticus species groups, respectively. Cluster 4 comprises Sle1 homogs from Macrococcus whereas cluster 5 includes homologs found in bacteria belonging to the Lactobacillales order and was the most distant. 


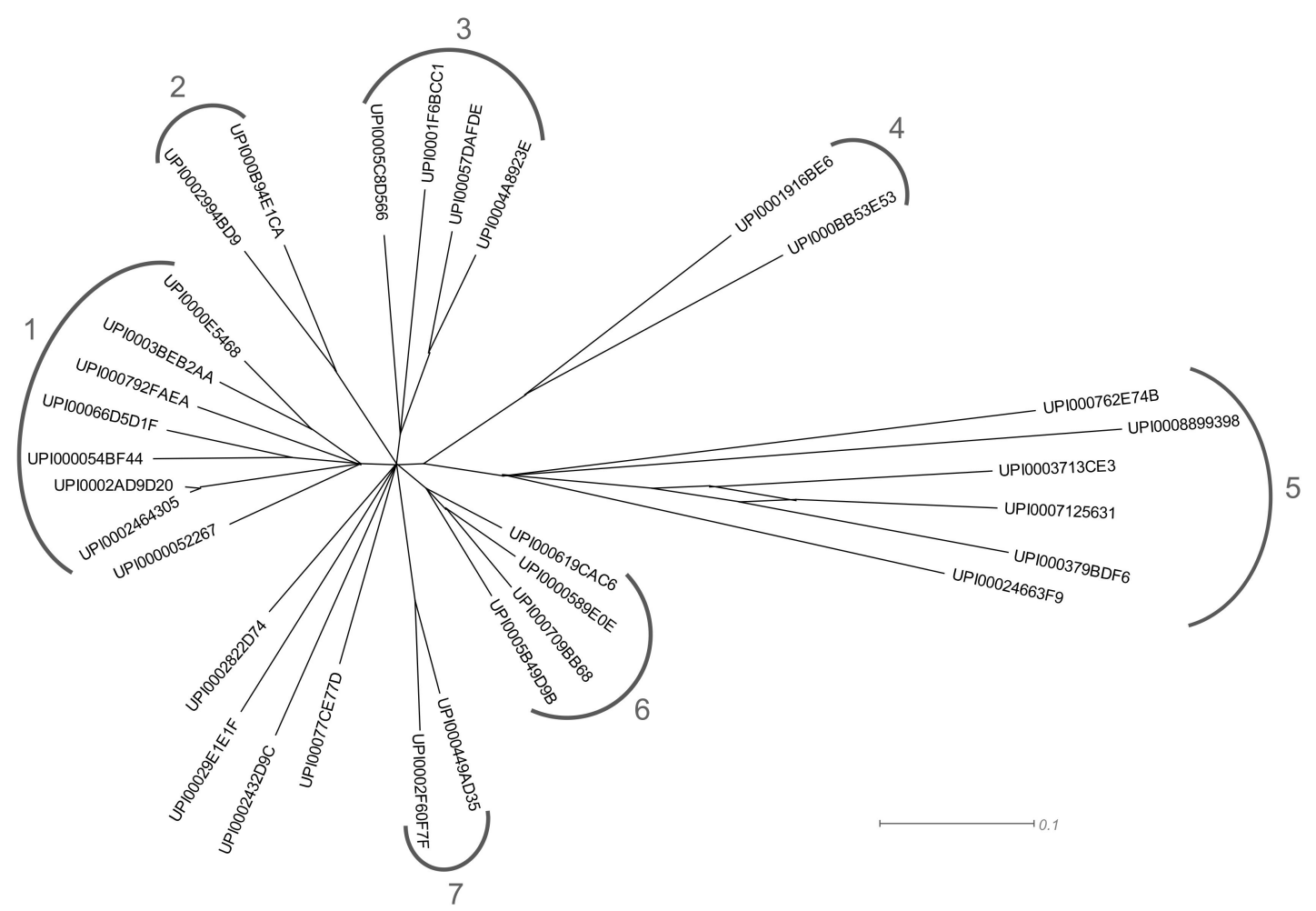

Figure 3. Phylogenetic tree based on Sle1 proteins (Table S2). The tree was constructed via SplitsTree4 by neighbor joining.

\subsection{Sle1 Active against Different Species of Staphylococcus}

The lytic activity of Sle1 from S. epidermidis RP62a was further tested on eight species of staphylococci as well as M. aurantiacus (Figure 4). Lysis was observed for all staphylococci but not for the Micrococcus strain. The percentages of lysis were quite variable and ranged from $30 \%$ (against S. xylosus) to about $80 \%$ (against S. sciuri, S. aureus, S. simulans) after $2 \mathrm{~h}$. Against S. sciuri $(69 \%)$ and S. haemolyticus (65\%) lysis occurred very quickly (within $30 \mathrm{~min}$ ).

Sle1 was also able to lyse 11 different strains of S. epidermidis, but with various efficacies depending on the strains (Figure 5A). The highest activity (59\%) was noted against the strain RP62A and the lowest (30\%) for S04-038. Similarly, four strains of S. aureus were studied and lysis reached a high percentage for the strain UAMS-1 (80\%) and a lower one for the strain SA113 (59\%). The S30 strain was really sensitive since $60 \%$ of the lysis was observed after $0.5 \mathrm{~h}$ incubation (Figure $5 \mathrm{~B}$ ). The observed lysis was higher for the strains of S. aureus than for the strains of S. epidermidis (Figure 5). A mixture of S. epidermidis RP62A and S. aureus UAMS-1 in a 1:1 ratio was incubated with Sle1 extract. Sixty-one percent lysis was assayed for the mixture after $3 \mathrm{~h}$ of incubation (data not shown). In parallel, enumeration was carried out and at T0 was $8.3 \log$ CFU/mL for the three populations (S. epidermidis RP62A, S. aureus UAMS-1, and the mixture of both) and a reduction of 3.0, 2.4 and $2.6 \log \mathrm{CFU} / \mathrm{mL}$ was measured after $3 \mathrm{~h}$ of incubation with Sle1 extract for S. aureus UAMS-1, S. epidermidis RP62A and the mixture, respectively. 


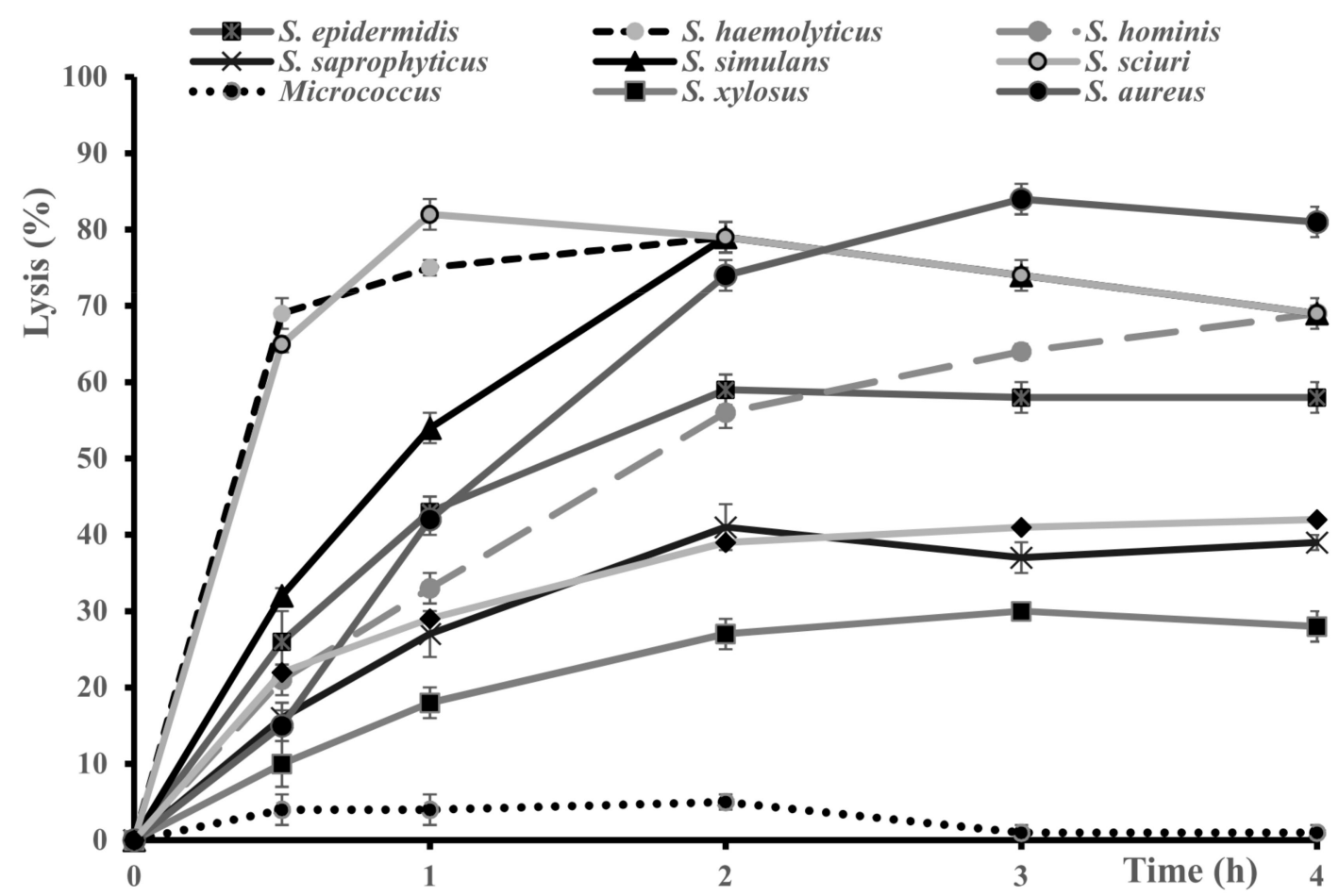

Figure 4. Lytic activity of Sle1 crude protein extract at $\mathrm{pH} 7.0$ and $37{ }^{\circ} \mathrm{C}$ on several species of Staphylococcus and on Micrococcus aurantiacus (S. epidermidis RP62A, S. haemolyticus CIP $81.56^{\mathrm{T}}$, S. hominis CIP $81.57^{\mathrm{T}}$, S. saprophyticus CIP $76.125^{\mathrm{T}}$, S. simulans DSM20273, S. sciuri CIP 81.62 ${ }^{\mathrm{T}}$, S. xylosus C2a, S. aureus UAMS-1, S. hyicus DSM 20459 ${ }^{\mathrm{T}}$, M. aurantiacus ATCC 11731). Cells lysis was monitored at $\mathrm{OD}_{600 \mathrm{~nm}}$ over time, the control extract was subtracted and lysis was expressed as a percentage from T0.

\subsection{Sle1 Active in Different Environnemental Conditions}

The lytic activity of Sle1 crude protein extract was compared to that of the CHAP domain alone. For this purpose, this domain was cloned into expression vector and expressed in E. coli as described above for the hydrolases. The CHAP crude protein extract had no lytic activity up to $2 \mathrm{~h}$ and a weak lytic activity between $15 \%$ and $10 \%$ after $4 \mathrm{~h}$ of incubation against S. epidermidis RP62A and S. aureus UAMS-1, respectively (data not shown).

The lytic activity of Sle1 was assayed at different temperatures and $\mathrm{pHs}$ against $\mathrm{S}$. epidermidis RP62A and S. aureus UAMS-1 (Figure 6). Lysis was maximal at $30^{\circ} \mathrm{C}$, and followed by $20^{\circ} \mathrm{C}$ and then $37^{\circ} \mathrm{C}$. Lysis was still measured at 10 and $4{ }^{\circ} \mathrm{C}$ (Figure $6 \mathrm{~A}, \mathrm{~B}$ ). The lytic activity at $37^{\circ} \mathrm{C}$ was close at $\mathrm{pH}$ 5.5 and 7.0 while it was lower at $\mathrm{pH} 9.0$ (Figure 6C,D).

The Sle1 enzyme extract kept its activity after one night at $4{ }^{\circ} \mathrm{C}$ or at room temperature. It had the same activity in Tris buffer and in physiological saline solution (data not shown). 
A

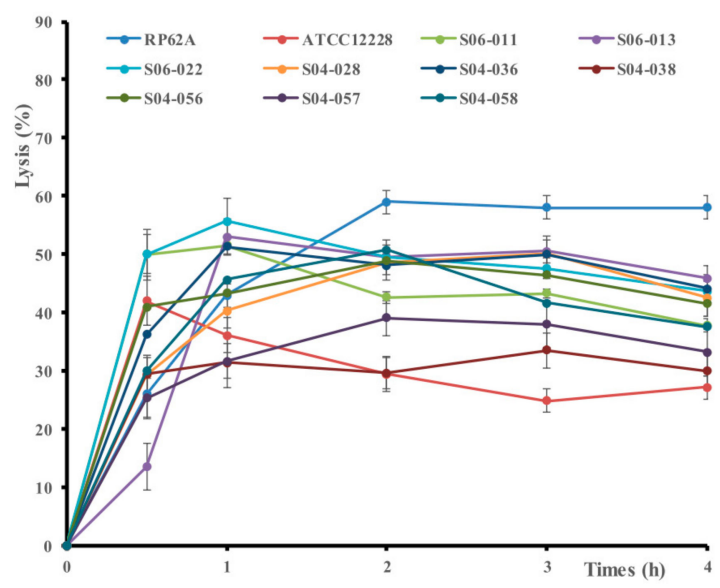

B

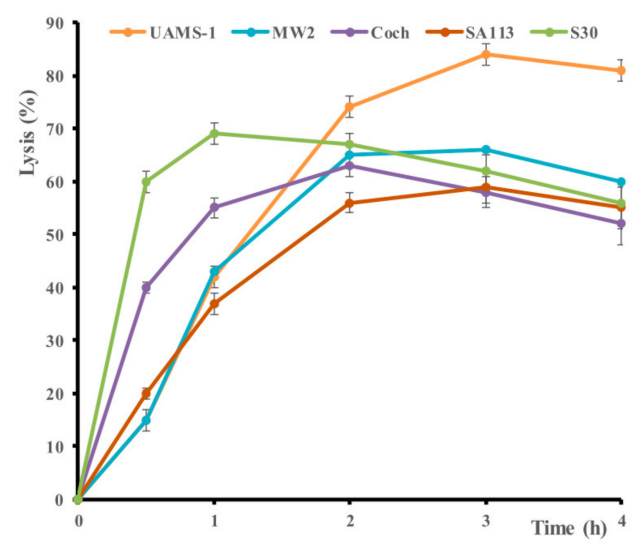

Figure 5. Lytic activity of Sle1 extract at $\mathrm{pH} 7.0$ and $37^{\circ} \mathrm{C}$ on (A) eleven strains of Staphylococcus epidermidis and (B) five strains of Staphylococcus aureus. Cell lysis was monitored at $\mathrm{OD}_{600 \mathrm{~nm}}$ over time, the control extract was subtracted and lysis was expressed as a percentage from T0.

A

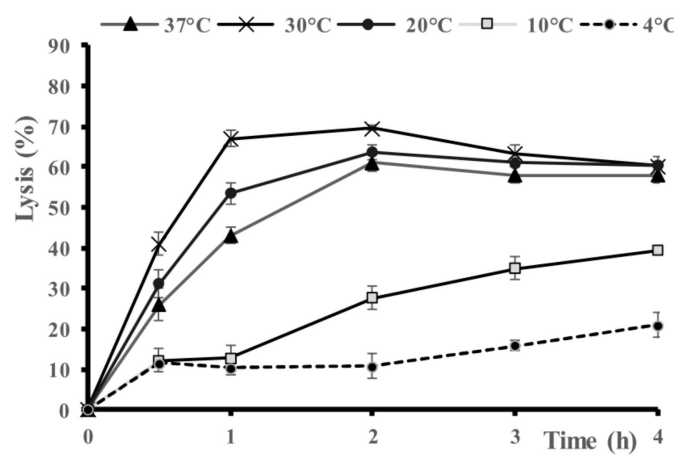

$\mathrm{C}$

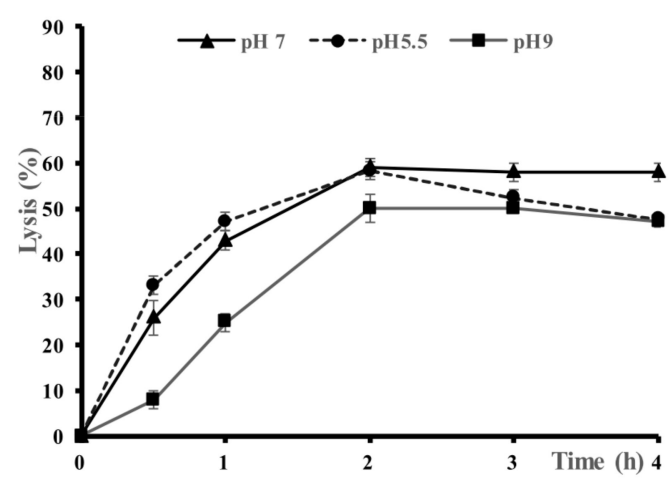

B

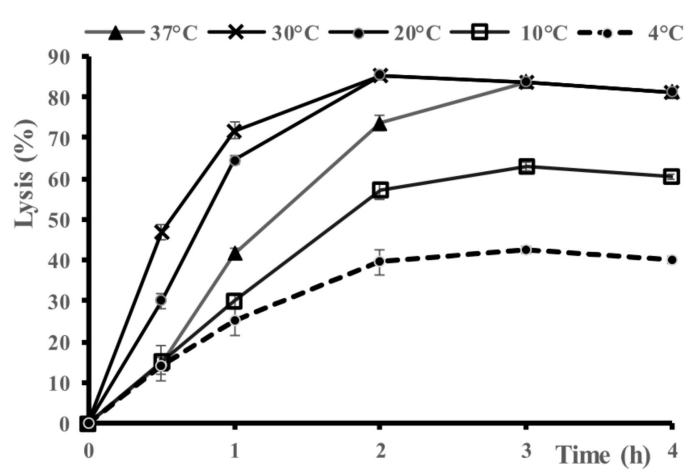

$\mathrm{D}$

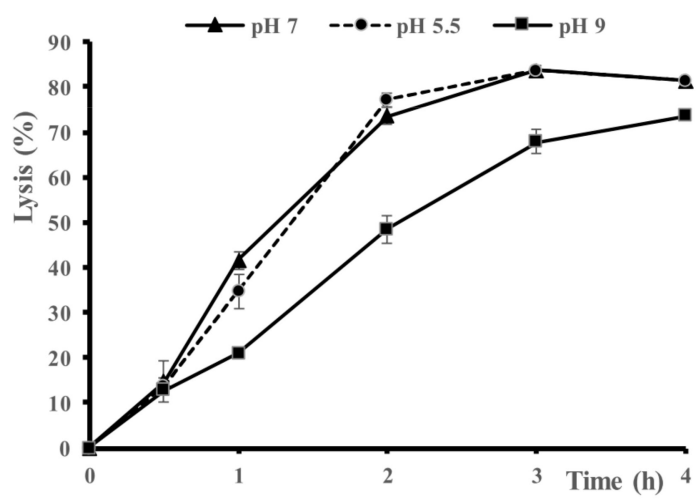

Figure 6. Lytic activity of Sle1 extract at $\mathrm{pH} 7.0$ and different temperatures on (A) Staphylococcus epidermidis RP62A and (B) Staphylococcus aureus UAMS-1 and at $37{ }^{\circ} \mathrm{C}$ and different pHs on (C) S. epidermidis RP62A and (D) S. aureus UAMS-1. Cell lysis was monitored at $\mathrm{OD}_{600 \mathrm{~nm}}$ over time, the control extract was subtracted and lysis was expressed as a percentage from T0.

The activity of Sle1 was also tested on biofilms of the S. epidermidis ATCC 12228 and S. aureus MW2 strains, these strains forming more biofilm than the strains RP62A and UAMS-1, respectively, in 
our experimental conditions (data not shown). The Sle1 extract was able to detach adhered cells of S. epidermidis and S. aureus, by $45 \%$ and $60 \%$ less, respectively, than the control extract (Figure 7).

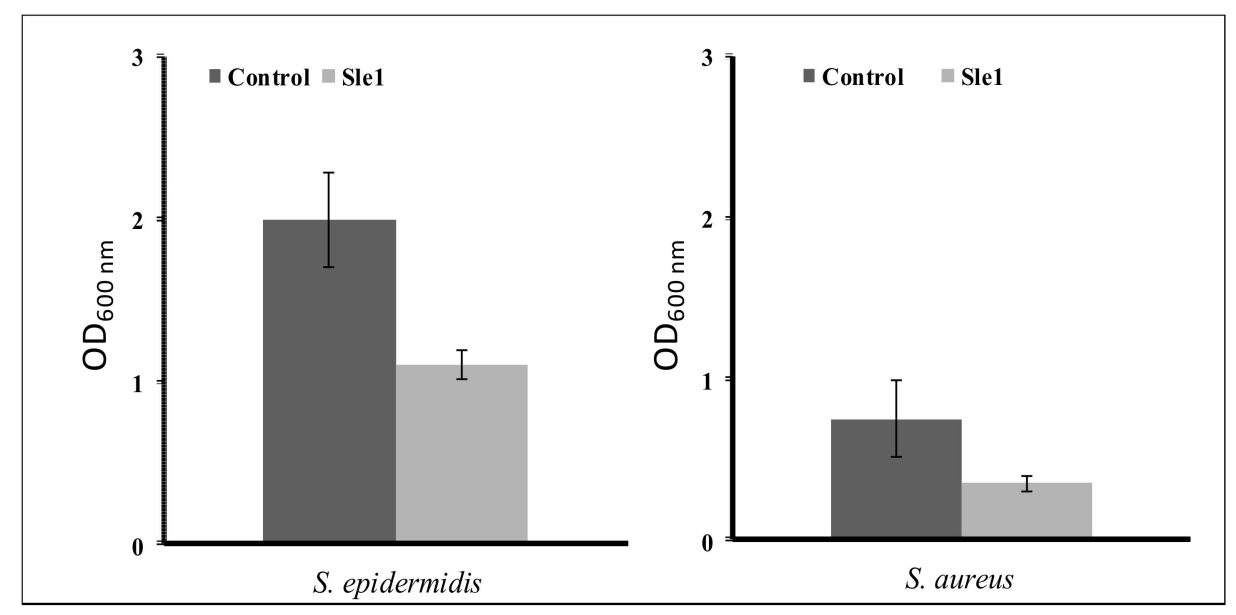

Figure 7. Effect of Sle1 extract on biofilm of Staphylococcus epidermidis ATCC 12228 and Staphylococcus aureus MW2.

\section{Discussion}

Of the 16 CWHs identified in the strain S. epidermidis RP62A, 14 have not yet been reported in S. epidermidis, while two, Atl and Sle1, have already been identified in S. epidermidis and mainly characterized for their adhesive properties [6,40]. LytH, which we identified in S. epidermidis, has already been studied in S. aureus just like Sle1 [41]. Moreover, SERP1330, SER1891 and SRP2263 are homologous to LytX, LytY, and LytZ from S. aureus, respectively [23]. In our study, the CHAP domain was found in nine CWHs out of the 16 identified in S. epidermidis RP62A. This domain is found in a wide range of protein architectures [20]. It was also identified in $11 \mathrm{CWHs}$ in 12 strains of S. aureus and in 44 staphylococcal phages [42]. It is associated with the CWA or CWG domain in 2 CWHs of S. epidermidis RP62A (Figure 1) and five in S. aureus [42].

A representative set of the three categories of CWHs, namely CWGs, CWAs and CWPs, was tested for their lytic activity against living cells of $S$. epidermidis RP62A. The two CWGs and the transglycosylase did not show any lytic activities (Figure 2). The CWG SERP0043 belongs to the glycoside hydrolase family GH-25. The structure resolution of the GHF-25 protein $\mathrm{LytC}$, from Streptococcus pneumoniae, revealed that this enzyme was only able to hydrolyze non-cross-linked peptidoglycan chains [43]. The other CWG SERP1330 belongs to the GH-73 family. The structure of the GH-73 from Listeria monocytogenes revealed that it is inactive when newly secreted but activated by proteolytic cleavage [44]. In E. coli, transglycosylase and transpeptidase (peptidoglycan synthases) formed enzymatic complexes with CWHs and are involved in cell division and cell wall rearrangement [45-47]. The CWA LytH of S. epidermidis RP62A, composed of an NALAA-3 catalytic domain and an SH3 anchoring one, lysed living cells of $S$. epidermidis while LytH from S. aureus was not able to lyse $S$. aureus living cells [41]. In S. aureus, its absence was correlated with methicillin resistance [24].

The three bifunctional enzymes we studied, AtlE (CWA/CWG), SERP1650 (CWP/CWA) and SERP2263 (CWG/CWP) lysed living cells of S. epidermidis. Atl was the most efficient and is one of the most studied CWHs in staphylococci. The domain arrangement of the Atl precursor protein is conserved among the staphylococci [15]. In S. aureus and S. epidermidis, Atl is post-translocationally processed between the propeptide and amidase domain and between the repeat anchoring domains [15]. In the S. epidermidis strain RP62A, it could be between the fourth and fifth SH3-8 (Figure 1) to free amidase SH3-8 (4 repeats) and glycosidase SH3-8 (2 repeats). The Western blot analysis of the Atl crude protein extract revealed two bands that could correspond to the native enzyme and the amidase. The lytic 
activity of Atl has been little explored, whereas its involvement in cell division, adhesive properties and biofilm formation and its protective effect against immunity have been widely studied [13-17,48,49].

The four CWPs studied (Figure 2) lysed living cells of S. epidermidis RP62A. They are all composed of a CHAP catalytic domain and variable LysM anchoring domains. The lytic activity increased with the number of LysM, with Sle1 with three LysM being the most active. Due to the high lytic activity of Sle1 against S. epidermidis RP62A, we focused on this CWH. Sle1, formerly named Aae for S. epidermidis and Aaa for S. aureus, has only been reported in these two species $[6,18,22,50]$.

Sle1 harbors a CHAP catalytic domain and three LysM domains. We first confirmed the role of LysM domains in lysis by showing that CHAP extract had a low activity compared to Sle1 extract. LysM domains of Sle1 of S. aureus direct murein hydrolases to the staphylococcal envelope [19]. The LysM domains bind to the repeating disaccharide of staphylococcal peptidoglycan. Sle1 of S. aureus requires at least two or three LysM domains to properly localize to the cell division septum [19]. The CHAP catalytic domain could act as a peptidase or an amidase [20]. In S. aureus, Sle1 was shown to act preferentially as an amidase and was involved in cell separation [18]. The CHAP catalytic domain of $S$. aureus LytN functions as both an amidase and a peptidase and promotes peptidoglycan separation [23]. In S. epidermidis and S. aureus, Sle1 has essentially been characterized for its adhesive properties to extracellular matrix proteins, but it also shows lytic activity, albeit only on heat-inactivated cells of Staphylococcus carnosus [6].

In this study, Sle1 homologs appeared to be distributed into seven distinct clusters and were identified in 24 staphylococcal species but also in Macrococcus, in bacteria from the Lactobacillale order and in Gram-positive and Gram-negative bacteria belonging to different genera. Within a given species, Sle1 homologs belonging to different clusters could be identified. The diversity of CHAP domains is apparent from phylogenetic analysis of 12 sequenced genomes of S. aureus and reveals three categories: i) proteins identified in all the genomes and with the CHAP domain at the C-terminal region, ii) proteins identified in three of the 12 genomes, encoded by chromosome and/or by plasmid and with the CHAP domain at the $\mathrm{C}$-terminal region, and iii) proteins not identified in all genomes, with the CHAP domain at the N-terminal region prophage-encoded [42].

Our study demonstrated a broad spectrum of lysis against living cells of nine different species of staphylococci. Lysis was recorded against living cells of different strains of S. epidermidis and S. aureus. A large spectrum of lysis of staphylococcal species was also noted for the mutant CW hydrolase LysF1 (CHAP domain and SH3b binding domain) from the staphylococcal bacteriophage 812F1 [51]. Like Sle1, LysF1 exhibited different antibacterial activities. In LysF1, this difference could be attributed to the effect of the binding domain SH3b on the different peptidoglycans [51]. Engineered phage derived lytic enzymes such as LysF1 improved their potential as antimicrobials and open new possibilities to tackle bacterial infections [52]. Sle1 was active at different temperatures between 37 and $4{ }^{\circ} \mathrm{C}$, at different $\mathrm{pHs}$ between 5.5 and 9 and at $145 \mathrm{mM} \mathrm{NaCl}$. LysK from a staphylococcal phage harboring a CHAP domain had a strong activity between $\mathrm{pH} 6$ and 9 and showed increasing activity from $150 \mathrm{mM}$ to $400 \mathrm{mM} \mathrm{NaCl}$ [53]. Similarly, the hydrolase of staphylolytic Twort phage with a CHAP domain had a maximum activity at $300 \mathrm{mM} \mathrm{NaCl}$ [54]. The activities of $S$. aureus lysostaphin and LytM, two other peptidases that harbor PM23 as catalytic domain, depended differently on $\mathrm{pH}$ : they were marginally active at $\mathrm{pH}$ 6.0, very active at $\mathrm{pH} 7.0$ to 9.0 for lysostaphin and $\mathrm{pH} 8.0$ to 9.0 for LytM [55].

Sle1 of S. epidermidis RP62A was able to detach sessile cells of S. epidermidis and S. aureus from abiotic surfaces. To date, the role of CWHs in the disruption of biofilm was essentially documented for lysostaphin, which can eradicate S. aureus biofilms, at least when the strains are not lysostaphin-resistant, but also S. epidermidis biofilms if higher concentrations of enzyme are used [56].

\section{Conclusions}

S. epidermidis has several CWHs with different lytic potentials. One of them, Sle1, exhibited a broad spectrum of staphylococcal lysis. It was active at different temperatures, $\mathrm{pHs}$, in saline solution, against planktonic and sessile cells of S. epidermidis and S. aureus strains. If further studies show the 
activity of Sle1 in in vivo models, it could be an alternative or a complementary therapy to antibiotic treatment for infections caused by staphylococci.

Supplementary Materials: The following are available online at http://www.mdpi.com/2076-2607/7/11/559/s1, Figure S1: Western blot analysis of cell-wall hydrolase crude protein extracts, Table S1: Primers used in this study, Table S2: The amino acid sequences of Sle1were searched in the UniProt data base using the Sle1 sequence of $S$. epidermidis RP62A as template.

Author Contributions: A.V., R.T., M.D., and S.L. designed the study and analyzed the data, A.V. and C.A. performed the experiments, A.V., R.T., M.D., C.P. and S.L. contributed to the writing and editing.

Funding: This study was supported in part by INRA (Institut National de la Recherche Agronomique), the DéEESe project from the Région Auvergne. Dr Aurore Vermassen, a post-doctoral research fellow was supported by a Bourse Innovation Transfert de Technologie from the Région Auvergne, FEDER (Fonds Européen de Développement Régional), and BioFilm Control.

Conflicts of Interest: The authors declare no conflict of interest.

\section{References}

1. Nagase, N.; Sasaki, A.; Yamashita, K.; Shimizu, A.; Wakita, Y.; Kitai, S.; Kawano, J. Isolation and species distribution of staphylococci from animal and human skin. J. Vet. Med. Sci. 2002, 64, 245-250. [CrossRef] [PubMed]

2. Becker, K.; Heilmann, C.; Peters, G. Coagulase-negative staphylococci. Clin. Microbiol. Rev. 2014, 27, 870-926. [CrossRef] [PubMed]

3. Vandecandelaere, I.; Van Nieuwerburgh, F.; Deforce, D.; Coenye, T. Metabolic activity, urease production, antibiotic resistance and virulence in dual species biofilms of Staphylococcus epidermidis and Staphylococcus aureus. PLoS ONE 2017, 12, e0172700. [CrossRef] [PubMed]

4. Zarb, P.; Coignard, B.; Griskeviciene, J.; Muller, A.; Vankerckhoven, V.; Weist, K.; Goossens, M.; Vaerenberg, S.; Hopkins, S.; Catry, B.; et al. The European Centre for Disease Prevention and Control (ECDC) pilot point prevalence survey of healthcare-associated infections and antimicrobial use. Euro Surveill. 2012, 17, 20316. [CrossRef] [PubMed]

5. Otto, M. Staphylococcal infections: Mechanisms of biofilm maturation and detachment as critical determinants of pathogenicity. Annu. Rev. Med. 2013, 64, 175-188. [CrossRef] [PubMed]

6. Heilmann, C.; Thumm, G.; Chhatwal, G.S.; Hartleib, J.; Uekotter, A.; Peters, G. Identification and characterization of a novel autolysin (Aae) with adhesive properties from Staphylococcus epidermidis. Microbiology 2003, 149, 2769-2778. [CrossRef] [PubMed]

7. Oliveira, M.; Bexiga, R.; Nunes, S.F.; Carneiro, C.; Cavaco, L.M.; Bernardo, F.; Vilela, C.L. Biofilm-forming ability profiling of Staphylococcus aureus and Staphylococcus epidermidis mastitis isolates. Vet. Microbiol. 2006, 118, 133-140. [CrossRef] [PubMed]

8. Periasamy, S.; Joo, H.S.; Duong, A.C.; Bach, T.H.; Tan, V.Y.; Chatterjee, S.S.; Cheung, G.Y.; Otto, M. How Staphylococcus aureus biofilms develop their characteristic structure. Proc. Natl. Acad. Sci. USA 2012, 109, 1281-1286. [CrossRef] [PubMed]

9. Buttner, H.; Mack, D.; Rohde, H. Structural basis of Staphylococcus epidermidis biofilm formation: Mechanisms and molecular interactions. Front. Cell. Infect. Microbiol. 2015, 5, 14. [CrossRef] [PubMed]

10. Vermassen, A.; Leroy, S.; Talon, R.; Provot, C.; Popowska, M.; Desvaux, M. Cell Wall Hydrolases in Bacteria: Insight on the Diversity of Cell Wall Amidases, Glycosidases and Peptidases Toward Peptidoglycan. Front. Microbiol. 2019, 10, 331. [CrossRef] [PubMed]

11. Szweda, P.; Schielmann, M.; Kotlowski, R.; Gorczyca, G.; Zalewska, M.; Milewski, S. Peptidoglycan hydrolases-potential weapons against Staphylococcus aureus. Appl. Microbiol. Biotechnol. 2012, 96, 1157-1174. [CrossRef] [PubMed]

12. Schneewind, O.; Fowler, A.; Faull, K.F. Structure of the cell wall anchor of surface proteins in Staphylococcus aureus. Science 1995, 268, 103-106. [CrossRef] [PubMed]

13. Biswas, R.; Voggu, L.; Simon, U.K.; Hentschel, P.; Thumm, G.; Götz, F. Activity of the major staphylococcal autolysin Atl. FEMS Microbiol. Lett. 2006, 259, 260-268. [CrossRef] [PubMed] 
14. Bourgeois, I.; Camiade, E.; Biswas, R.; Courtin, P.; Gibert, L.; Götz, F.; Chapot-Chartier, M.P.; Pons, J.L.; Pestel-Caron, M. Characterization of AtlL, a bifunctional autolysin of Staphylococcus lugdunensis with $\mathrm{N}$-acetylglucosaminidase and $\mathrm{N}$-acetylmuramoyl-l-alanine amidase activities. FEMS Microbiol. Lett. 2009, 290, 105-113. [CrossRef] [PubMed]

15. Götz, F.; Heilmann, C.; Stehle, T. Functional and structural analysis of the major amidase (Atl) in Staphylococcus. Int. J. Med. Microbiol. 2014, 304, 156-163. [CrossRef] [PubMed]

16. Nair, N.; Vinod, V.; Suresh, M.K.; Vijayrajratnam, S.; Biswas, L.; Peethambaran, R.; Vasudevan, A.K.; Biswas, R. Amidase, a cell wall hydrolase, elicits protective immunity against Staphylococcus aureus and S. epidermidis. Int. J. Biol. Macromol. 2015, 77, 314-321. [CrossRef] [PubMed]

17. Hussain, M.; Steinbacher, T.; Peters, G.; Heilmann, C.; Becker, K. The adhesive properties of the Staphylococcus lugdunensis multifunctional autolysin AtlL and its role in biofilm formation and internalization. Int. J. Med. Microbiol. 2015, 305, 129-139. [CrossRef] [PubMed]

18. Kajimura, J.; Fujiwara, T.; Yamada, S.; Suzawa, Y.; Nishida, T.; Oyamada, Y.; Hayashi, I.; Yamagishi, J.; Komatsuzawa, H.; Sugai, M. Identification and molecular characterization of an N-acetylmuramyl-L-alanine amidase Sle1 involved in cell separation of Staphylococcus aureus. Mol. Microbiol. 2005, 58, 1087-1101. [CrossRef] [PubMed]

19. Frankel, M.B.; Schneewind, O. Determinants of murein hydrolase targeting to cross-wall of Staphylococcus aureus peptidoglycan. J. Biol. Chem. 2012, 287, 10460-10471. [CrossRef] [PubMed]

20. Bateman, A.; Rawlings, N.D. The CHAP domain: A large family of amidases including GSP amidase and peptidoglycan hydrolases. Trends Biochem. Sci. 2003, 28, 234-237. [CrossRef]

21. Rigden, D.J.; Jedrzejas, M.J.; Galperin, M.Y. Amidase domains from bacterial and phage autolysins define a family of gamma-D,L-glutamate-specific amidohydrolases. Trends Biochem. Sci. 2003, 28, 230-234. [CrossRef]

22. Hirschhausen, N.; Schlesier, T.; Peters, G.; Heilmann, C. Characterization of the modular design of the autolysin/adhesin Aaa from Staphylococcus aureus. PLoS ONE 2012, 7, e40353. [CrossRef] [PubMed]

23. Frankel, M.B.; Hendrickx, A.P.; Missiakas, D.M.; Schneewind, O. LytN, a murein hydrolase in the cross-wall compartment of Staphylococcus aureus, is involved in proper bacterial growth and envelope assembly. J. Biol. Chem. 2011, 286, 32593-32605. [CrossRef] [PubMed]

24. Fujimura, T.; Murakami, K. Staphylococcus aureus clinical isolate with high-level methicillin resistance with an lytH mutation caused by IS1182 insertion. Antimicrob. Agents Chemother. 2008, 52, 643-647. [CrossRef] [PubMed]

25. Gill, S.R.; Fouts, D.E.; Archer, G.L.; Mongodin, E.F.; Deboy, R.T.; Ravel, J.; Paulsen, I.T.; Kolonay, J.F.; Brinkac, L.; Beanan, M.; et al. Insights on evolution of virulence and resistance from the complete genome analysis of an early methicillin-resistant Staphylococcus aureus strain and a biofilm-producing methicillin-resistant Staphylococcus epidermidis strain. J. Bacteriol. 2005, 187, 2426-2438. [CrossRef] [PubMed]

26. Delmas, J.; Chacornac, J.P.; Robin, F.; Giammarinaro, P.; Talon, R.; Bonnet, R. Evaluation of the Vitek 2 system with a variety of Staphylococcus species. J. Clin. Microbiol. 2008, 46, 311-313. [CrossRef] [PubMed]

27. Götz, F.; Zabielski, J.; Philipson, L.; Lindberg, M. DNA homology between the arsenate resistance plasmid pSX267 from Staphylococcus xylosus and the penicillinase plasmid pI258 from Staphylococcus aureus. Plasmid 1983, 9, 126-137. [CrossRef]

28. Stenz, L.; Francois, P.; Fischer, A.; Huyghe, A.; Tangomo, M.; Hernandez, D.; Cassat, J.; Linder, P.; Schrenzel, J. Impact of oleic acid (cis-9-octadecenoic acid) on bacterial viability and biofilm production in Staphylococcus aureus. FEMS Microbiol. Lett. 2008, 287, 149-155. [CrossRef] [PubMed]

29. Friedman, L.; Alder, J.D.; Silverman, J.A. Genetic changes that correlate with reduced susceptibility to daptomycin in Staphylococcus aureus. Antimicrob. Agents Chemother. 2006, 50, 2137-2145. [CrossRef] [PubMed]

30. Mitchell, A.L.; Attwood, T.K.; Babbitt, P.C.; Blum, M.; Bork, P.; Bridge, A.; Brown, S.D.; Chang, H.Y.; El-Gebali, S.; Fraser, M.I.; et al. InterPro in 2019: Improving coverage, classification and access to protein sequence annotations. Nucleic Acids Res. 2019, 47, D351-D360. [CrossRef] [PubMed]

31. Finn, R.D.; Coggill, P.; Eberhardt, R.Y.; Eddy, S.R.; Mistry, J.; Mitchell, A.L.; Potter, S.C.; Punta, M.; Qureshi, M.; Sangrador-Vegas, A.; et al. The Pfam protein families database: Towards a more sustainable future. Nucleic Acids Res. 2016, 44, D279-D285. [CrossRef] [PubMed]

32. Letunic, I.; Doerks, T.; Bork, P. SMART 6: Recent updates and new developments. Nucleic Acids Res. 2009, 37, D229-D232. [CrossRef] [PubMed] 
33. Marchler-Bauer, A.; Bo, Y.; Han, L.; He, J.; Lanczycki, C.J.; Lu, S.; Chitsaz, F.; Derbyshire, M.K.; Geer, R.C.; Gonzales, N.R.; et al. CDD/SPARCLE: Functional classification of proteins via subfamily domain architectures. Nucleic Acids Res. 2017, 45, D200-D203. [CrossRef] [PubMed]

34. Nagl, S.B. Function prediction from protein sequence. In Bioinformatics: Genes, Proteins and Computers; Orengo, D.T., Thornton, J.M., Eds.; BIOS Scientific Publishers: Oxford, UK, 2003; pp. 64-78.

35. Bradford, M.M. A rapid and sensitive method for the quantitation of microgram quantities of protein utilizing the principle of protein-dye binding. Anal. Biochem. 1976, 72, 248-254. [CrossRef]

36. Camacho, C.; Coulouris, G.; Avagyan, V.; Ma, N.; Papadopoulos, J.; Bealer, K.; Madden, T.L. BLAST+: Architecture and applications. BMC Bioinform. 2009, 10, 421. [CrossRef] [PubMed]

37. Consortium, U. The universal protein resource (UniProt). Nucleic Acids Res. 2008, 36, D190-D195. [CrossRef] [PubMed]

38. Notredame, C.; Higgins, D.G.; Heringa, J. T-Coffee: A novel method for fast and accurate multiple sequence alignment. J. Mol. Biol. 2000, 302, 205-217. [CrossRef] [PubMed]

39. Huson, D.H.; Bryant, D. Application of phylogenetic networks in evolutionary studies. Mol. Biol. Evol. 2006, 23, 254-267. [CrossRef] [PubMed]

40. Heilmann, C.; Hussain, M.; Peters, G.; Götz, F. Evidence for autolysin-mediated primary attachment of Staphylococcus epidermidis to a polystyrene surface. Mol. Microbiol. 1997, 24, 1013-1024. [CrossRef] [PubMed]

41. Osipovitch, D.C.; Therrien, S.; Griswold, K.E. Discovery of novel S. aureus autolysins and molecular engineering to enhance bacteriolytic activity. Appl. Microbiol. Biotechnol. 2015, 99, 6315-6326. [CrossRef] [PubMed]

42. Zou, Y.; Hou, C. Systematic analysis of an amidase domain CHAP in 12 Staphylococcus aureus genomes and 44 staphylococcal phage genomes. Comput. Biol. Chem. 2010, 34, 251-257. [CrossRef] [PubMed]

43. Perez-Dorado, I.; Gonzalez, A.; Morales, M.; Sanles, R.; Striker, W.; Vollmer, W.; Mobashery, S.; Garcia, J.L.; Martinez-Ripoll, M.; Garcia, P.; et al. Insights into pneumococcal fratricide from the crystal structures of the modular killing factor LytC. Nat. Struct. Mol. Biol. 2010, 17, 576-581. [CrossRef] [PubMed]

44. Bublitz, M.; Polle, L.; Holland, C.; Heinz, D.W.; Nimtz, M.; Schubert, W.D. Structural basis for autoinhibition and activation of Auto, a virulence-associated peptidoglycan hydrolase of Listeria monocytogenes. Mol. Microbiol. 2009, 71, 1509-1522. [CrossRef] [PubMed]

45. Holtje, J.V. Growth of the stress-bearing and shape-maintaining murein sacculus of Escherichia coli. Microbiol. Mol. Biol. Rev. 1998, 62, 181-203. [PubMed]

46. Holtje, J.V. A hypothetical holoenzyme involved in the replication of the murein sacculus of Escherichia coli. Microbiology 1996, 142, 1911-1918. [CrossRef] [PubMed]

47. Scheffers, D.J.; Pinho, M.G. Bacterial cell wall synthesis: New insights from localization studies. Microbiol. Mol. Biol. Rev. 2005, 69, 585-607. [CrossRef] [PubMed]

48. Bose, J.L.; Lehman, M.K.; Fey, P.D.; Bayles, K.W. Contribution of the Staphylococcus aureus Atl AM and GL murein hydrolase activities in cell division, autolysis, and biofilm formation. PLoS ONE 2012, 7, e42244. [CrossRef] [PubMed]

49. Zoll, S.; Patzold, B.; Schlag, M.; Götz, F.; Kalbacher, H.; Stehle, T. Structural basis of cell wall cleavage by a staphylococcal autolysin. PLoS Pathog. 2010, 6, e1000807. [CrossRef] [PubMed]

50. Heilmann, C.; Hartleib, J.; Hussain, M.S.; Peters, G. The multifunctional Staphylococcus aureus autolysin aaa mediates adherence to immobilized fibrinogen and fibronectin. Infect. Immun. 2005, 73, 4793-4802. [CrossRef] [PubMed]

51. Benešík, M.; Nováček, J.; Janda, L.; Dopitová, R.; Pernisová, M.; Melková, K.; Tišáková, L.; Doškař, J.; Žídek, L.; Hejátko, J.; et al. Role of SH3b binding domain in a natural deletion mutant of Kayvirus endolysin LysF1 with a broad range of lytic activity. Virus Genes 2018, 54, 130-139. [CrossRef] [PubMed]

52. São-José, C. Engineering of phage-derived lytic enzymes: Improving their potential as antimicrobial. Antibiotics 2018, 7, 29. [CrossRef] [PubMed]

53. Becker, S.C.; Foster-Frey, J.; Donovan, D.M. The phage K lytic enzyme LysK and lysostaphin act synergistically to kill MRSA. FEMS Microbiol. Lett. 2008, 287, 185-191. [CrossRef] [PubMed]

54. Becker, S.C.; Swift, S.; Korobova, O.; Schischkova, N.; Kopylov, P.; Donovan, D.M.; Abaev, I. Lytic activity of the staphylolytic Twort phage endolysin CHAP domain is enhanced by the SH3b cell wall binding domain. FEMS Microbiol. Lett. 2015, 362, 1-8. [CrossRef] [PubMed] 
55. Sabala, I.; Jonsson, I.M.; Tarkowski, A.; Bochtler, M. Anti-staphylococcal activities of lysostaphin and LytM catalytic domain. BMC Microbiol. 2012, 12, 97. [CrossRef] [PubMed]

56. Robinson, S.; Lenfant, M.; Wdzieczak-Bakala, J.; Melville, J.; Riches, A. The mechanism of action of the tetrapeptide acetyl-N-Ser-Asp-Lys-Pro (AcSDKP) in the control of haematopoietic stem cell proliferation. Cell. Prolif. 1992, 25, 623-632. [CrossRef] [PubMed] 